\title{
Inovasi Pelayanan Publik Di Desa Seberang Taluk Kabupaten Kuantan Singingi
}

\author{
${ }^{1}$ Ikhsan, ${ }^{2}$ Syofian, ${ }^{3}$ Bunga Chintia Utami \\ ${ }^{1}$ Program Studi Ilmu Hukum Universitas Riau, Indonesia \\ ${ }^{2}$ Program Studi Ilmu Administrasi Publik Universitas Riau, Indonesia \\ ${ }^{3}$ Program Studi Ekonomi Pembangunan Universitas Riau, Indonesia \\ e-mail: ikhsan@lecturer.unri.ac.id
}

\begin{abstract}
Abstrak
Tujuan Penelitian ini mendeskripsikan inovasi pelayanan publik dalam keterbukaan informasi publik pada pemerintahan desa. Metode penelitian ini mengunakan studi kepustakaan primer, wawancara, observasi dan dokumentasi, adapun teknik analisis data mengunakan model interaktif. Penelitian ini menemukan bahwa inovasi pelayanan publik dilakukan ditingkat desa dapat dilakukan dengan level inovasi Incremental dan dilakukan secara terus-menerus tanpa harus merubah atau penemuan sama sekali baru, faktor pendorong keberhasilan inovasi di lokasi penelitian kerjasama, partisipasi, komitmen, fleksibel, transparansi dan sarana prasana inovasi pelayanan. Temuan penelitian dapat dijadikan rujukan bagi peneliti bidang hukum, administrasi publik dan pembangunan ekonomi pedesaan.
\end{abstract}

Keywords: Inovasi, Pelayanan Publik, Informasi, Kepala Desa, Pemerintahan Desa.

\begin{abstract}
The purpose of this research describes the innovation of public services in public information disclosure in village governance. This research method uses primary literature studies, interviews, observations, and documentation, as well as data analysis techniques using interactive models. This research found that public service innovations are carried out by the village to be done with an Incremental innovation level and done continuously without having to change or a new invention, the driving factor of innovation success in the cooperation research site, participation, commitment, flexibility, transparency and infrastructure facilities Innovation service. Research findings can be used as a reference for legal researchers, public administration, and rural economic development
\end{abstract}

Kata Kunci : Innovation. Public Services, Informations, a village head, village government.

\section{PENDAHULUAN}

Implementasi Undang-Undang Desa Nomor 6 Tahun 2014 memberikan ruang kepada Pemerintahan Desa untuk mewujudkan otonomi asli desa selain itu dalam implementasi kebijakan ini juga memberikan peluang kepada desa untuk mempercepat pembangunan desa karena diikuti pembangian keuangan kepada desa yang terus meningkat. Kebijakan ini juga memberikan kewenangan yang luas dalam kerangka implementasi otonomi desa. Namun semenjak implementasi kebijakan ini mendorong bermunculan penelitian-penelitian tentang otonomi desa dan efektivitas dana (Dewanta, 2016) karena adanya fenomena transparan, partispasi dan kurangnya kepercayaan publik (Imawan, Irianto, \& Prihatiningtias, 2019), (Febri Arifiyanto \& Kurrohman, 2014), (Hanifah \& Sugeng, 2015) dan fenomena penggunaan anggaran 
desa (Kumalasari, 2017). Penelitian terdahulu ini melihat kekurangan dalam implementasi undangundang desa nomor 06 tahun 2014.

Penelitian ini berbeda dalam melihat fonomena pemerintahan desa dari penelitian yang telah direview mereka lebih fokus melihat fenomena pemerintahan dari segi kelemahan yang terjadi pada pemerintahan desa. Kelemahan tata kelola pemerintahan desa dalam akuntabilitas (Imawan et al., 2019). Permasalahan penelitian ini menurut peneliti menarik berkaitan dengan adanya prestasi pemerintahan desa dalam pelayanan publik berkaitan dengan keterbukaan informasi publik. Pelayanan publik merupakan kewajiban bagi lembaga-lembaga publik dengan menerapkan prinsip keterbukaan dalam mengelola lembaga publik. Pemerintahan Desa merupakan salah satu lembaga publik yang diberikan kewenangan otonom dalam mengelola desa dan pelayanan publik kepada masyarakat sesuai Permendagri Nomor 2 tahun 2017 tentang Standar Pelayanan Minimal Desa. Selain itu adanya kewenangan otonom pemerintahan desa didorong untuk melakukan pembaharuan melalui program inovasi ditingkat desa yang diatur melalui Peraturan Menteri Desa PDTT Nomor 4 Tahun 2019 tentang Perubahan atas Keputusan Menteri Desa, Pembangunan Daerah Tertinggal, dan Transmigrasi Nomor 48 Tahun 2018 tentang Pedoman Umum Program Inovasi Desa Perubahan ini pedoman umum PID tersebut, dikarenakan adanya perubahan subtansi pada pengaturan terkait Pedoman Umum Program Inovasi Desa, menyangkut inovasi, layanan teknis, dan kegiatan peningkatan kapasitas dalam mendukung program pencegahan stunting pada praktik pembangunan desa.

Pelayanan publik pada pemerintahan desa berdasarkan Undang-Undang nomor 6 tahun 2014 tentang desa merupakan pelayanan jasa pemerintahan, pelayanan sosial, dan kegiatan ekonomi. Desa berkewajiban dalam meningkatkan pelayanan publik bagi warga masyarakat Desa guna mempercepat perwujudan kesejahteraan umum, kualitas pelayanan publik dengan menerapkan Prinsip partisipasi, prinsip supremasi hukum, transparansi, prinsip responsivitas, akuntabilitas, (Tomuka, 2013) adopsi dari UNDP yang akan meningkatkan kepercayaan publik dalam pelayanan publik. Berkaitanan dengan itu salah satu Pemerintahan Desa di Kabupaten Kuantan Singingi melakukan Inovasi Pelayanan Publik yang fokus pada Inovasi Layanan Teknis yang dilakukan oleh pemerintahan desa. Inovasi pelayanan ini berkaitan dengan adanya keterbukaan informasi publik dengan kegiatan pemerintahan, pembangunan desa, penggunaan anggaran desa.

Pemerintahan Desa yang berhasil adalah pemerintahan Desa Seberang Taluk Kabupaten Kuantan Singingi mencapai Penerimaan piagam penghargaan secara langsung dari Menteri PDT di Jakarta, sebagai desa terbaik kedua se Indonesia, setelah Desa Pejambon Bojonogoro, Provinsi Jawa Timur. Penilaian Inovasi Pelayanan ini merupakan penilaian pada bidang keterbukaan informasi dan pelayanan publik berskala Nasional dari 33 Provinsi se Indonesia menurut Emil Harda Kepala Desa Periode 20132019 (Riau Terkini, Kamis, 29 Nopember 2018 18:12). Presetasi pelayanan keterbukaan informasi ini menjadi dasar ketertarikan peneliti untuk melakukan penelitian di desa Seberang Taluk Kabupaten Kuantan Singingi.

Keberhasilan pelayanan keterbukaan informasi dilihat secara nasional merupakan peringkat 2 nasional, namun apabila kita lihat dari segi diluar pulau jawa Desa Seberang Taluk Kabupaten Kuantan Singingi terbaik secara nasional. Hal inilah mendorong pertanyaan penelitian dengan melihat bagaimana inovasi pelayanan publik bidang keterbukaan publik ini bisa dicapai oleh Pemerintahan Desa Seberang Taluk Kabupaten Kuantan Singingi ?

Tujuan penelitian ini adalah mendeskripsikan dan menjelaskan bagaimana inovasi pelayanan publik bidang keterbukaan publik Desa Seberang Taluk Kabupaten Kuantan Singingi yang mendorong keberhasilan inovasi pelayanan publik bidang keterbukaan informasi publik. 


\section{METODE}

Penelitian ini mengunakan metode penelitian kualitatif untuk menjelaskan permasalahan. Penelitian ini berlokasi di Desa Seberang Taluk Kecamatan Kuantan Tengah Kabupaten Kuantan Singingi. Dalam penelitian dipilih metode kualitatif karena mempertimbangkan maslaah empiris yang merupakan asumsiasumsi yang membutuhkan ekplorasi yang mendalam dan lebih detil agar dapat dijelaskan secara konfrehesif dan objektif (Hasbiansyah, 2004). Dalam penelitian ini mengunakan data primer dan data sekunder. Subjek penelitian yang diambil adalah Kepala Desa satu orang, Ketua BPD satu orang, mantan kepala desa satu orang, perangkat desa dua orang, kepala dusu dua orang, anggota BPD satu orang tokoh masyarakat 1 orang, dan masyarakat 3 orang mewakili dusun-dusun yang ada. Jadi jumlah subjek informan penelitian adalah 12 orang.

Penelitian ini dalam mengumpulkan mengunakan teknik observasi, wawancara, dan dokumentasi. Kemudian dilakukan analisis data dengan tiga tahapan setelah diperoleh data dari lapangan dengan melakukan reduksi data, display data dan kesimpulan (Miles, Huberman, \& Saldana, 2014). Kegiatan penelitian agar mendapatkan derajat kepercayaan tinggi, dan dapat dipertanggungjawabkan selaku instrument utama penelitian maka peneliti melakukan triangulasi data. Triagulasi adalah proses mencocokan data dengan kroscek dan validasi hasil antara satu data dengan data yang lain baik berupa data sekunder maupun data primer yang diperoleh secara empiris untuk dilakukan perbandingan dari informan data yang dipilih. Kemudian kegiatan selanjutnya mengorganisasikan data, analisis dan mengambil kesimpulan hasil penelitian. Hasil dari kegiatan ini selanjutnya digunakan untuk menjelaskan permasalahan yang telah diteliti secara factual dan obejektif sesuai dengan temuan-temuan yang diperoleh secara empiris.

\section{HASIL DAN PEMBAHASAN}

\section{Inovasi Pelayanan Publik Bidang Keterbukaan Publik}

Desa Seberang Taluk merupakan desa yang berada di Kecamatan Kuantan Tengah ibu Kota Kabupaten Kuantan Singingi diantar 22 desa lainnya. Desa Seberang Taluk Memiliki 5 Dusun 6 RW dan 12 RT dengan jumlah perangkat desa 10 orang 1 perempuan dan 9 laki-laki dengan jumlah penduduk 1.943 jiwa dengan 961 laki-laki dan perempuan 982 dengan kepadatan penduduk 324 dari 6 Kilo Meter Persegi luas wilayah perbandingan dari 1.943 jumlah penduduk. Rata-rata jumlah penduduk dari 493 Rumah Tangga adalah 4 (Badan Pusat Statistik, 2019).

Dengan jumlah penduduk dan luas wilayah ini pemerintahan desa melakukan proses pelayanan secara terbuka dan partisipatif dengan potensi sumber daya manusia yang dimiliki Desa Seberang Taluk diambil sebagai peluang oleh Kepala Desa (2019 sudah mantan Kepala Desa) untuk meningkatkan pelayanan, diketahui juga bahwa Kepala Desa juga memiliki Pendidikan Cukup Tinggi yakni Strata 2 Magister Manajemen.

Hasil Penelitian ini secara empiris diperoleh dari Informan Penelitian Kunci yaitu Kepala Desa (Bapak Ir.Emil Harda,MM) mejelaskan bahwa inovasi pelayanan publik bidang keterbukaan informasi publik diperoleh karena adanya kelengkapan sarana dan prasarana pelayanan, fakta integritas seluruh BPD proses pemerintahah dan partisipasi masyarakat, transparansi. 


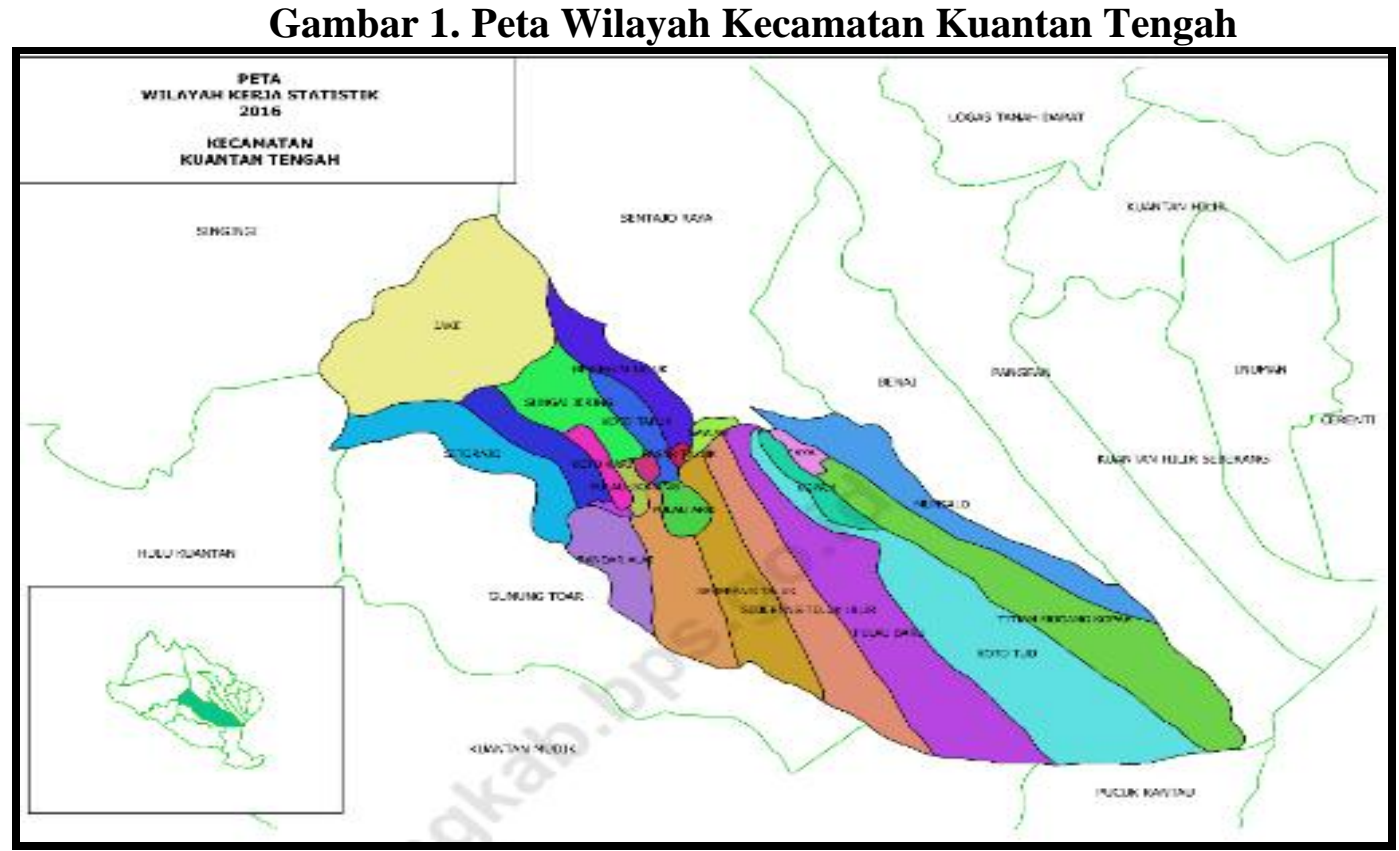

Sumber: BPS Kuantan Singingi 2019

Inovasi Pelayanan yang dilakukan oleh Pemerintahan Desa Seberang Taluk merupakan hasil penilaian dari Direktur Jenderal Pembangunan dan Pemberdayaan Masyarakat Desa (PPMD) Kemendes PDTT sebagai penghargaan dan apresiasi terhadap desa dan kerja keras para pejuang desa dengan kategori, yakni kategori penguatan pembangunan dan pemberdayaan masyarakat desa; kategori prioritas penggunaan dana desa dan padat karya tunai; kategori prakarsa dan inovatif; dan kategori pelayanan informasi dan transparansi publik.

Penghargaan yang diterima oleh pemerintahan Desa Seberang Taluk merupakan penerima penghargaan desa terbaik kategori pelayanan informasi dan transparansi publik di antaranya Desa Pejambon, Kecamatan Sumberrejo, Kabupaten Bojonegoro; Desa Seberang Taluk, Kecamatan Kuantan Tengah, Kabupaten Kuantan Singingi; dan Desa Bhuana Jaya, Kecamatan Tenggarong Seberang, Kabupaten Kutai Kertanegara (PDDT, 2018).

Inovasi Pelayanan yang dilakukan oleh Desa Seberang Taluk dilihat levelnya menurut peneliti berkaitan dengan pendapat Muluk adaopsi dari Mulgan dan Albury dalam (Fitriana, 2014) berada pada level inceremental dimana inovasi yang dilakukan membawa perubahan-perubahan kecil kepada proses atau layanan yang ada. Secara umum inovasi pada level ini jarang mebawa perubahan terhadap struktur organisasi dan hubungan keorganisasian. Namun level ini mempunyai peran penting dalam proses pembaharuan sektor publik karena dapat mewujudkan perubahan kecil yang dapat diterapkan secara terus menerus dan mendukung kerangka pelayanan yang responsive terhadap kebutuhan lokal dan perorangan, serta mendukung nilai tambah dalam pelayanan baik secara materi maupun modal sosial.

Bentuk level inovasi pelayanan yang dilakukan oleh pemerintahan desa Seberang Taluk Kabupaten Kuantan Singingi berdasarkan data empiris yang didapat oleh peneliti, adanya fakta integritas seluruh BPD dan seluuruh perangkat Desa dalam proses pelayanan informasi perencanaan, pembangunan dan pengelolaan pemerintahan desa. Hal ini sesuai hasil wawancara peneliti dengan informan penelitian yang diwakili BPD dan Perangkat mereka menjawab dengan hamper sama' semenjak adanya fakta integritas setiap rapat perencanaan pembangunan BPD dan perangkat hadir dan berpartisipasi tanpa merubah peran struktur dan keorganisasian yang telah ada dalam undang-undanng tentang desa berserta peraturan pendukung pelaksanaannya'. 
Bentuk level inovasi pelayanan berikutnya adalah dengan meningkatkan partisipasi masyarakat desa dengan melibatkan masyarakat secara keseluruhan dengan sistem menghadirkan masyarakat pada saat musyawarah perencanaan, proses pembangunan, secara perwakilan kepala keluarga. Selanjutnya desa memberikan informasi melalui website dan fasilitas umum tentang kegiatan pemerintahan yang akan dilakukan dan yang telah dilakukan, berdasarkan data empiris peneliti menemukan proses pengumuman dan pencanangan di Mesjid-mesjid, Baliho tentang penggunaan APBdes dengan ukuran $3 \times 4$ meter, papan plang kegiatan.

Partispasi masyarakat berbentuk aspirasi dan kritik dan saran masyarakat. Kelompok pemuda, remaja masjid, kelompok tani, kelompok perempuan, PKK dan yasinan," Kata Kepala Desa Seberang Taluk Kabupaten Kuantan Singingi dan palayanan Juga ditambahkan oleh Kepala Desa antara waktu Magrib dan waktu Isya di rumah atau ditempat ibadah. Berdasarkan data empiris ini peneliti melihat kategori Inovasi berdasarkan pendapat Muluk dikutip (Fitriana, 2014) bahwa ini merupakan Sustaining Innovation (Inovasi terusan) yang merupakan inovasi dilihat dari proses perubahan baru namun tetap berdasarkan pada kondisi pelayanan serta sistem yang berjalan atau produk yang sudah ada bukan merupakan kategori inovasi terputus yang merupakan inovasi yang membawa perubahan sama seklai baru dan tidak lagi berdasarkan aturan atau konsisi yang sudah ada sbelumnya. Karena Kepala Desa, BPD, Perangkat dan mayarakat tidak merubah keorganisasian namun lebih kepada melakukan pelayanan lebih transparansi dan terbuka berdasarkan fungsi kelembagaan yang ada. Ini sesuai dengan penelitian (Syofian \& F.S, 2020) bahwa informasi pelayanan kana meningkatkan kepercayaan publik dan partisipasi mayarakat desa.

Keberhasilan inovasi ini dilihat dari tipologinya menurut Mulgan dan Alburi dikutip (Fitriana, 2014) merupakan hasil kreasi dan inovasi implementasi dari ouput layanan, progress layanan, metode layanan, kebijakan layanan dan inovasi sistem. Pada penelitian Keterbukaan Informasi Publik merupakan tipologi layanan layanan dan dilakukan dengan kebersamaan merupakan inovasi proses pelayanan. Proses atau kegiatan perencanaan dan pembangunan lebih didominasi oleh kepala desa sebelumnya dirubah menjadi kebersamaan dengan adanya fakta integritas antara kepala desa, perangkat desa dan seluruh anggota BPD di Desa Seberang Taluk. Fakta integritas ini merupakan metode layanan yang akan diterima oleh masyarakat karena stakeholders berkewajiban dalam memberikan informasi berdasarkan fakta integrita yang sudah ditanda tangani yang merupakan cara baru dalam meningkatkan kepercayaan publik dan transparansi proses pemerintahan. Sedangkan Partisipasi Mayarakat melalui perwakilan kepala keluarga merupakan bentuk sistem layanan apa yang diminta seluruh perwakilan keluarga berdasasrkan musyawarah yang telah diputuskan sudah diketahui oleh perwakilan-perwakilan keluarga apa yang dicapai oleh pemerintahan desa yang dimasukkan dalam fakta integritas sehingga ini menjadi pendorong untuk meningkatkan partisipasi dan responsivitas pemerintahan desa yang menambah tingkat kepercayaan publik. Tipologi Inovasi Kebijakan merupakan hasil dari Keputusan dalam APBDes yang telah diputusakan bersama berupa penggunaan anggaran dan kegiatan yang disampaikan baik secara online, tempat-tempat umum dan pelayanan diluar jam kantor yang telah dimplementasikan oleh Pemerintahan Desa Seberang Taluk Kecamatan Kuantan Tengah Kabupaten Kuantan Singingi.

Tipologi sistem inovasi pelayanan yang memberikan kepercayaan, transparansi mayarakat desa telah mendorong Desa Seberang Taluk berhasil dalam meraih prestasi sebagai Desa Inovatif yang diterima oleh pemerintahan Desa Seberang Taluk merupakan penerima penghargaan desa terbaik kategori pelayanan informasi dan transparansi publik.

Berdasarkan hasil penelitian empiris yang dilakukan peneliti menemukan bahwa inovasi pelayanan secara incremental dapat mendorong keberhasilan inovasi keterbukaan informasi publik pada pemerintahan desa dengan menerapkan partisipasi, komitmen, responsive, empati pada kelompok sasaran pelayanan publik. 


\section{Faktor Pendorong Keberhasilan Inovasi Pelayanan Publik Bidang Keterbukaan Publik}

Hasil penelitian empiris yang dilakukan menemukan faktor keberhasilan inovasi pelayanan publik dibidang Keterbukaan Informasi Publik di Desa Seberang Taluk Kecamatan Kuantan Tengah Kabupaten Kuantan Singingi sebagai berikut:

\section{Kerja sama}

Pemerintahan Desa Seberang Taluk Kecamatan Kuantan Tengah berhasil dalam melakukan inovasi pelayanan publik bidang keterbukaan informasi publik dan meningkatkan kepercayaan publik dan transparansi informasi karena dorongan keberhasilan kepala desa dalam mengajak perangkat desa, BPD dan mayarakat untuk saling bekerjasama dalam memberikan informasi mulai dari proses perencanaan, pelaksanaan dan evaluasi baik itu pembangunan, pemberdayaan, pengelolaan keuangan yang dilakukan pemerintah desa dan tidak adanya perbedaan data dari Pemerintah Desa dan BPD. Selain itu kerjasama yang terjadi dalam perencanaan diikuti oleh Kepala Keluarga masyarakat desa dalam proses pembangunan infrasruktur dan pemberdayaan masyrakat desa dengan informasi yang disampaikan melalui tempat umum dan online.

\section{Faktor Partisipasi}

Pemerintahan Desa Seberang Taluk Kecamatan Kuantan Tengah berhasil melakukan inovasi juga didorong oleh tingginya angka partisipasi BPD hadir dalam rapat perencanaan, pelaksanaan dan evaluasi proses pelayanan publik. Selain itu dengan bentuk tingginya partisipasi masyarakat melalui kepala keluarga yang ikut dalam perencananaan dan partisipasi warga dalam progress pembangunan dan pelayanan informasi melalui mulut ke mulut dilingkungan keluarganya juga mendorong partisipasi masyarakat yang memberikan kontribusi keberhasilan inovasi pelayanan publik.

\section{Faktor Komitmen}

Komitmen menjadi faktor pendorong yang sangat menentukan dalam inovasi pelayanan publik yang dilakukan oleh Pemerintahan Desa Seberang Taluk Kecamatan Kuantan Tengah Kabupaten Kuantan Singingi karena adanya Fakta Integritas yang dibuat oleh Kepala Desa, BPD dan Perangkat Desa yang disaksikan langsung oleh masyarakat desa melalui musyawarah dan informasi tempat-tempat umum dan secara online serta perwakilan keluarga menjadikan peningkatan transparansi dan keterbukaan informasi publik yang mereka dapat sehingga komitmen yang dibuat dijalankan sesuai dengan yang telah diptuskan.

\section{Faktor Fleksibel}

Inovasi pelayanan publik bidang keterbukaan informasi publik juga didorong oleh mudahnya layanan yang diterima oleh masyarakat, melalui bentuk pelayanan selain jam kerja kantor masyarakat dapat menerima layanan publik berkaitan dengan informasi dan pelayanan publik lainnya dirumah Kepala Desa dan tempat ibadah dengan waktu setelah shalat magrib dan setelah shalat isya hal ini berkaitan dengan sebagian warga masyarakat ada yang menjadi pedagang, petani dan pekerjaan kantor yang mendorong mereka hanya bisa mengurus pelayanan setelah jam kerja. Sehingga dengan tidak kaku atau fleksibel layanan ini menjadikan faktor keberhasil inovasi pelayanan.

\section{Transparansi}

Transparansi merupakan bentuk pemberian informasi kepada publik terhadap keputusan-keputusan, tindakan-tindakan yang dilakukan oleh organisasi publik dalam rangka meningkatkan dan menuju kepada tata kelola pemerintahan yang baik. Dengan adanya transparansi yang dilakukan oleh Pemerintahan Desa Seberang Taluk Kecamatan Kuantan Tengah Kabupaten Kuantan Singingi mendorong keberhasilan inovasi pelayanan publik, adapun bentuk transparansi pemberian informasi ditempat- tempat umum dan online serta sampai kepada kepala keluarga sesuai ketentuan yang berlaku.

\section{Sarana Prasarana}

Dasar pemilihan Desa Seberang Taluk berhasil dalam Inovasi Pelayanan Publik degan melengkapi seluruh sarana dan prasarana dalam rangka kategori transparansi dan inovasi informasi publik baik perangkat keras maupun lunak dalam pelayanan publik. Sarana kantor dan website telah dilengkapi dan 
infomrasi publik berupa pencanangan tradisonal,undangan kepada seluruh anggota BPD dan Seluruh Kepala Keluarga. Pengumuman ditempat umum seperti masjid-mesjid dan Baliho ukuran 3x4 Meter serta dilokasi kegiatan pembangunan juga dipasang palng informasi pembangunan desa dan pelayanan desa yang mengunakan APBDes. Selain itu kelompok-kelompok masyarakat dilibatkan untuk menampung aspirasi dan kritik dan saran masyarakat melalui kelompok pemuda, remaja masjid, kelompok tani, kelompok perempuan, PKK dan yasinan.

\section{KESIMPULAN}

Kesimpulan dari Penelitian ini menemukan bahwa Inovasi Pelayanan Publik yang diterapkan di Desa Seberang Taluk Kecamatan Kuantan Tengah Kabupaten Kuantan Singingi merupakan Inovasi Pelayanan Publik pada Level Incremental yang dilakukan kreasi oleh Kepala Desa dengan melibatkan BPD, Perangkat Desa, dan Masyarakat dengan ketentuan komitmen berupa fakta integritas Kepala Desa, BPD dan Perangkat Desa yang diketahui masyarakat desa melalui partisipasi yang selama ini terjadi di desa tidak ada komitmen bersama. Faktor yang mendorng keberhasilan inovasi desa ini adalah kerjasama, partisipasi, komitmen, fleksibel, transparansi dan sarana prasarana inovasi desa. Kategori inovasi yang dilakukan merupakan inovasi terus menerus tanpa mengubah organisasi, organisasional dan kelembagaan yang ada

\section{SARAN}

Dalam inovasi pelayanan publik pada tingkat pemerintahan desa secara prakmatis pemerintahan desa dapat adopsi yang telah dilakukan oleh pemerintahan desa tidak harus membuat cara sama sekali baru cukup secara Incremental dan berkelanjutan. Secara teoritis ini bisa menjadi rujukan dalam inovasi pelayanan publik bidang keterbukaan informasi publik untuk dilakukan kajian lebih lanjut dari perspektif hukum, administrasi publik dan pembangunan ekonomi masyarakat pedesaan

\section{DAFTAR PUSTAKA}

[1]. Aziz, N. L. L. (2016). Otonomi Desa dan Efektivitas Dana Desa. Jurnal Penelitian Politik, 13(2), 193-211.

[2]. Imawan, A., Irianto, G., \& Prihatiningtias, Y. W. (2019). Peran Akuntabilitas Pemerintah Desa Dalam Membangun Kepercayaan Publik. Jurnal Akuntansi Multiparadigma, 10(1).

[3]. Miles, M. B., Huberman, A. M., \& Saldaña, J. (2014). Qualitative Data Analysis: Methods Sourcebook. 3rd. ed: Thousand Oaks, CA: Sage.

[4]. Keputusan Gubernur Riau No. Kpts. 1058/XI/2016 Tentang Upah Minimum Kabupaten/Kota Se Provinsi Riau Tahun 2017

[5]. Dewanta, A. S. (2016). Otonomi dan Pembangunan Daerah. Jurnal Penelitian Politik, 13(2), $193-$ 211. https://doi.org/10.20885/unisia.vol27.iss53.art12 
[6]. Febri Arifiyanto, D., \& Kurrohman, T. (2014). Akuntabilitas Pengelolaan Alokasi Dana Desa Di Kabupaten Jember. Jurnal Riset Akuntansi Dan Keuangan, 2(3), 473. https://doi.org/10.17509/jrak.v2i3.6598

[7]. Fitriana, D. N. (2014). Inovasi Pelayanan Publik BUMN (Studi Deskriptif tentang Inovasi Boarding Pass System dalam Meningkatkan Kualitas Pelayanan Kereta Api PT KAI di Stasiun Gubeng Surabaya). Kebijakan Dan Manajemen Publik, 2(1), 1-10. Retrieved from http://www.journal.unair.ac.id/download-fullpapers-kmp3c8840fbddfull.pdf

[8]. Hanifah, S. I., \& Sugeng, P. (2015). Akuntabilitas dan Transparansi Pertanggungjawaban Anggaran Pendapatan Belanja Desa (APBDes). Jurnal Ilmu \& Riset Akuntansi, 4(8), 1-15.

[9]. Hasbiansyah, O. (2004). Konstelasi Paradigma Objektif dan Subjektif dalam Penelitian Komunikasi dan Sosial. Mediator, 5(2), 199-218.

[10].Imawan, A., Irianto, G., \& Prihatiningtias, Y. W. (2019). Peran Akuntabilitas Pemerintah Desa Dalam Membangun Kepercayaan Publik. Jurnal Akuntansi Multiparadigma, 10(1), 156-175. https://doi.org/10.18202/jamal.2019.04.10009

[11].Kumalasari, D. (2017). Transparansi Dan Akuntabilitas Pemerintah Desa Dalam Pengelolaan Alokasi Dana Desa. Jurnal Ilmu Dan Riset Akuntansi, 5(11), 1-15. Retrieved from https://ejournal.stiesia.ac.id/jira/article/view/2563

[12].Miles, M. B., Huberman, A. M., \& Saldana, J. (2014). Qualitatif Data Analysis A Methods Edition 3.

[13]. Syofian, \& Tua F S, H. (2019). Villagers' Satisfaction Indicators on Village Information System in The Front Region. Jurnal Niara, 12(2), 34- 43. https://doi.org/10.31849/niara.v12i2.3072.

[14].Tomuka, S. (2013). Penerapan Prinsip-Prinsip Good Governance Dalam Pelayanan Publik Di Kecamatan Girian Kota Bitung (Studi Tentang Pelayanan Akte Jual Beli). Jurnal Politico, 1(3), 115.

[14].Tomuka, S. (2013). Penerapan Prinsip-Prinsip Good Governance Dalam Pelayanan Publik Di Kecamatan Girian Kota Bitung (Studi Tentang Pelayanan Akte Jual Beli). Jurnal Politico, 1(3), 115. 